\title{
Benthic disturbance affects intertidal food web dynamics: implications for investigations of ecosystem functioning
}

\author{
Christopher P. Cesar ${ }^{1,2, *}$, Chris L. J. Frid ${ }^{1}$ \\ ${ }^{1}$ School of Environmental Sciences, University of Liverpool, Brownlow Street, Liverpool L69 3GP, UK \\ ${ }^{2}$ Present address: APEM, Riverview, A17 Embankment Business Park, Heaton Mersey, Stockport SK4 3GN, UK
}

\begin{abstract}
Analysis of biological traits within assemblages is increasingly used as a proxy for ecological functioning. However, taxa often show plasticity in the expression of traits and can potentially change trait expression depending on local conditions. While many forms of disturbance will lead to changes in the species composition of the assemblage, small-scale disturbances can trigger alterations in the behaviour of taxa and hence the ecological roles they are delivering. Such changes would not be detected by biological traits analysis (BTA) alone. BTA therefore has the potential to misinform as to the contribution of assemblages to ecological processes. To assess the potential for taxa to change their expression of traits, the feeding modes of 8 taxa from 2 intertidal assemblages in north-west England, UK, were investigated using stable isotope analyses following experimental sediment disturbance and removal of cockles Cerastoderma edule. Two of the 8 taxa exhibited significant changes to their isotopic composition within disturbed plots. Shortterm plastic changes to food web dynamics following changes in environmental conditions have implications for the suitability of BTA as a tool for investigating ecosystem function. Although BTA provides much insight into the ecological roles of taxa within systems and can be extremely effective at identifying changes associated with different assemblage compositions, it is conceivable that changes to ecological functioning may be undetected by BTA alone, and hence there is the need for this approach to be supported by experimental observation.
\end{abstract}

KEY WORDS: Trait plasticity - Ecosystem function - Anthropogenic impact - Biological traits analysis $\cdot$ BTA

\section{INTRODUCTION}

Investigations into the role of biodiversity in supporting the functioning of ecosystems have traditionally been based largely on taxonomic approaches, investigating how species richness, evenness and other indices influence the delivery of ecological functions such as primary production and nutrient regeneration (Jonsson \& Malmqvist 2000, Zak et al. 2003). Increasingly, these investigations are being supplemented by studies focused on the ecological roles played by individual taxa; considering, for example, the influence of ecology, behaviour and physiology on ecological processes (e.g. Bremner et al. 2006, Baird et al. 2008). Such studies typically map the occurrences of biological traits or phenotypes within assemblages, grouping taxa by the strategies they have evolved in order to feed, reproduce, move etc. Different strategies affect ecological processes to different extents; for example, bioturbation modes have differing impacts on nutrient cycling within the benthos (Mermillod-Blondin et al. 2005). If the taxa 
within assemblages differ, then the biological traits supplied by the assemblages may also differ. Formal biological traits analysis (BTA) generally assumes that taxa belong to rigid functional groups, offering no potential for organisms to change the traits they are expressing. A fuzzy coding approach allows taxa to express more than one trait category (Chevenet et al. 1994), though this approach still only provides a probabilistic description of the potential range of traits that an organism may be expressing. That is, it is impossible to define the actual, or realised, range of traits being expressed under any given set of environmental or experimental conditions.

Within naturally variable habitats, such as the temperate estuarine intertidal, such uncertainty potentially limits descriptions of ecological function. In these habitats, factors such as salinity, temperature, food availability and the risk of predation often show substantial temporal fluctuations (e.g. Froneman 2001). As such, taxa often show some degree of plasticity in their expression of biological traits, for example, adopting differing reproductive (Gudmundsson 1985, Wilson 1985, Anger et al. 1986), or feeding (Rönn et al. 1988, Esselink \& Zwarts 1989) strategies depending on localised conditions.

With the potential for variability in the expression of traits by taxa, it is difficult to discern the traits being expressed by a taxon at any given time and, therefore, the ecological roles being played. Consider, for example, a disturbance event that causes the individuals within an assemblage to alter their expression of some functionally important trait, but does not result in a change in the species composition of the assemblage. The ecological functioning of the system is altered; however, taxonomic based analyses and BTA would suggest that system functioning is unaltered. This has implications for the applicability of functional group and BTA, in that a change in how taxa are expressing ecologically important traits can mean that these approaches provide a misleading indication of the ecological roles that taxa within an assemblage are delivering.

We assessed the extent to which taxa within a benthic assemblage alter the traits they are expressing following disturbance. One trait that has the potential to show a high degree of plasticity is the 'feeding mode' adopted by organisms. Many taxa adopt different feeding preferences depending upon local conditions (Fauchald \& Jumars 1979 and references therein). A substantial body of literature describes the feeding modes of marine benthos, and the degree to which taxa express different feeding strategies is known to have the potential to change under chang- ing environmental conditions. The polychaete Hediste diversicolor O.F. Müller, for example, exhibits preferences for suspension or deposit feeding, as well as acting as an active predator, depending upon the availability of food resources (Rönn et al. 1988, Esselink \& Zwarts 1989). The feeding methods of taxa are of substantial ecological interest, with trophic relationships playing a fundamental role in the transfer of energy and organic carbon within ecosystems (e.g. Frid et al. 2008).

To assess the potential for changes in the feeding behaviour of taxa and food web dynamics within temperate intertidal assemblages, stable isotope signatures were analysed in taxa taken from experimental plots that had been subjected to physical disturbance and experimental fishing. Stable isotope ratios of carbon $\left(\delta^{13} \mathrm{C}\right)$ and nitrogen $\left(\delta^{15} \mathrm{~N}\right)$ were investigated as proxies of different food resources and trophic level, respectively. These manipulations were part of an investigation into the effect of a fishery for the cockle Cerastoderma edule on a number of ecological functions, including biodiversity, functional diversity and primary producer biomass (Cesar \& Frid 2009).

\section{MATERIALS AND METHODS}

\section{Site description and faunal sampling}

Experimental manipulations were carried out at 2 shores in north-west England, at Thurstaston within the Dee Estuary and Warton Sands within Morecambe Bay (Fig. 1). Macrofaunal assemblages at Thurstaston housed a greater species richness than those at Warton Sands (Cesar \& Frid 2009). Field manipulations and faunal sampling were carried out between June and September 2007. At each shore, 3 experimental treatments were applied to 4 replicate $2 \times 2 \mathrm{~m}$ plots arranged in a randomised block design:

(1) Cockles removed (fished): plots were handraked once (sediments disturbed to $\sim 10 \mathrm{~cm}$ depth) using methods analogous to those used by commercial cockle Cerastoderma edule fishers. Raked sediments were passed through a $20 \mathrm{~mm}$ wide square mesh and retained cockles removed. All other fauna were returned to the plots.

(2) Procedural control (raked): as in fished treatment, but all organisms (including $C$. edule) were returned to the sediment.

(3) Control: undisturbed plots.

Four months following the initial manipulations, faunal assemblages within the experimental plots 


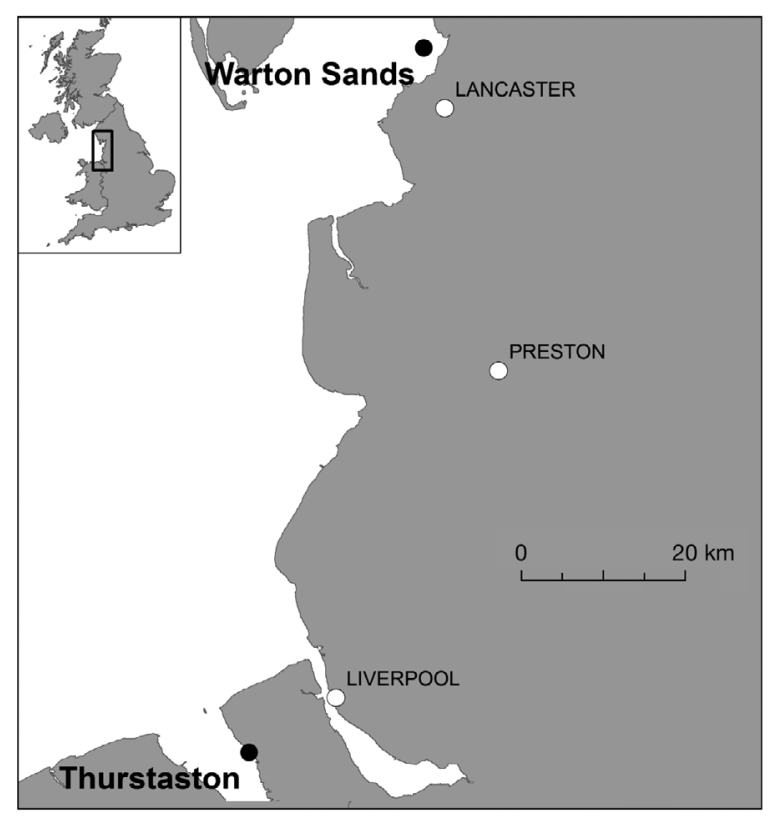

Fig. 1. Experimental systems in north-west England

were sampled and macrofauna fixed with $4 \%$ formaldehyde solution and stored in $70 \%$ ethanol solution. Those taxa present within at least 3 of the 4 replicate plots of each treatment were selected for stable isotope analysis. At Thurstaston, the bivalves Cerastoderma edule L., Macoma balthica (L.) and Mya arenaria (L.) and the annelids Tubificoides benedii (Udekem), Eteone longa (Fabricius) and Hediste diversicolor were analysed. C. edule and M. balthica from Warton Sands were analysed as well as the polychaetes Pygospio elegans (Claparède) and Nephtys hombergii (Savigny). These taxa display a range of feeding modes, have a wide range of potential diets (Table 1) and are likely to be important contributors to ecosystem functioning, representing $79.3 \%$ of macrofaunal biomass at Thurstaston and
$93.8 \%$ of macrofaunal biomass at Warton Sands (Cesar \& Frid 2009, C. P. Cesar unpubl. data).

\section{Sample preparation and stable isotope analysis}

Adults display different isotopic ratios than juveniles (Lorrain et al. 2002); therefore, analysed individuals of each species were of similar size. Preparation of tissue differed by species. Whole organisms of Tubificoides benedii, Eteone longa and Pygospio elegans were analysed, while the chitinous jaws were removed from Hediste diversicolor and Nephtys hombergii. The bivalves Cerastoderma edule, Macoma balthica and Mya arenaria were removed from their shells and muscular foot and gut tissue removed under a stereo microscope. Chitinous polychaete jaws and bivalve muscle tissue typically have longer turnover rates and hence take longer to assimilate changes to dietary isotope content than do more metabolically active viscera (Lorrain et al. 2002). Given the relatively short time period of the experimental manipulation (4 mo), these tissues were excluded from this study. Samples were rinsed in deionised water and dried at $60^{\circ} \mathrm{C}$ for $48 \mathrm{~h}$. Dried samples were thoroughly homogenised to a powder using a mortar and pestle.

Dried powdered aliquots (ca. $1.25 \mathrm{mg}$ ) were packed into $8 \times 5 \mathrm{~mm}$ tin capsules. Ratios of stable carbon and nitrogen isotopes $\left(\delta^{13} \mathrm{C}\right.$ and $\left.\delta^{15} \mathrm{~N}\right)$ were ascertained using the elemental analyser of a continuous flow isotope ratio mass spectrometer (PDZ Europa 20/20, UC Davis Stable Isotope Facility). All isotope data were expressed in standard $\delta$ notation (measured as \%o), comparing the ratio of the heavy:light isotope to standard reference materials, Pee Dee belemnite for carbon and atmospheric $\mathrm{N}_{2}$ for nitrogen.

Table 1. Taxa selected for stable isotope analysis to determine the impacts of benthic disturbance on the realised feeding niche in benthic assemblages. The taxa chosen show a number of feeding modes with the potential to exploit a range of food resources

\begin{tabular}{|c|c|c|c|}
\hline Taxon & Feeding mode & Primary food resource & Source \\
\hline Cerastoderma edule & $\begin{array}{l}\text { Suspension/ } \\
\text { re-suspended benthos }\end{array}$ & $\begin{array}{l}\text { Plankton, particulate matter, } \\
\text { microphytobenthos }\end{array}$ & $\begin{array}{l}\text { Kamermans (1993), (1994), Sauriau } \\
\text { \& Kang (2000) }\end{array}$ \\
\hline Macoma balthica & Deposit/suspension & Plankton, microphytobenthos & de Goeij \& Luttikhuizen (1998) \\
\hline Mya arenaria & Suspension & Plankton & Nichols (1985) \\
\hline Tubificoides benedii & Deposit & Particulate matter & Powell et al. (1983), Giere et al. (1984) \\
\hline Eteone longa & Predator & Invertebrates & $\begin{array}{l}\text { Fauchald \& Jumars (1979), Michaelis } \\
\text { \& Vennemann (2005) }\end{array}$ \\
\hline Hediste diversicolor & Opportunistic & $\begin{array}{l}\text { Plankton, particulate matter, } \\
\text { invertebrates }\end{array}$ & $\begin{array}{l}\text { Rönn et al. (1988), Esselink \& Zwarts } \\
\text { (1989), Vedel (1998) }\end{array}$ \\
\hline Pygospio elegans & Deposit/suspension & Plankton, particulate matter & Fauchald \& Jumars (1979) \\
\hline Nephtys hombergii & Predator & Invertebrates & Fauchald \& Jumars (1979) \\
\hline
\end{tabular}


Fixing and preserving faunal samples in formalin and ethanol, respectively, may potentially affect the interpretation of the data, having some, though generally limited, effect on $\delta^{13} \mathrm{C}$ and $\delta^{15} \mathrm{~N}$ values (Sarakinos et al. 2002). The principle aim of this investigation, however, was not to investigate food-web dynamics per se but to investigate whether disturbances have the potential to change feeding behaviour within a faunal assemblage. As all faunal tissue samples spent an equal amount of time in preservative fluids and the tissues of conspecifics were treated in the same manner, comparisons between treatments are valid.

\section{Statistical analyses}

For the 2 taxa present at both Thurstaston and Warton Sands (Cerastoderma edule and Macoma balthica), isotope ratios were compared with an ANOVA, with Experimental Treatment, Species and Shore as factors. The remaining 6 taxa were present only on a single shore (Tubificoides benedii, Eteone longa, Hediste diversicolor and Mya arenaria at Thurstaston and Nephtys hombergii and Pygospio elegans at Warton Sands) and were assessed using the factors Treatment and Species. Where significant differences were observed $(\alpha=$ 0.05), post-hoc pairwise comparisons were made between factors using the Bonferroni pair-wise procedure.

\section{RESULTS}

Species differed in the ratios of both carbon $\left(F_{1,24}=115.19, \mathrm{p}<0.001\right.$ and $F_{5,36}=68.73, \mathrm{p}<0.001$ for species found on both or single shores, respectively) and nitrogen $\left(F_{1,24}=249.46, \mathrm{p}<\right.$ 0.001 and $F_{5,36}=217.26, \mathrm{p}<0.001$ for species found on both or single shores, respectively) within their tissues. This suggests that taxa were utilising a range of food sources (differing in their $\delta^{13} \mathrm{C}$ values) and occupying multiple trophic levels (differing in their $\delta^{15} \mathrm{~N}$ values), with predatory taxa, i.e. Eteone longa and Nephtys hombergii, showing higher $\delta^{15} \mathrm{~N}$ values than primary consumers, in particular Pygospio elegans, Macoma balthica and Mya arenaria (Fig. 2).
The polychaete Nephtys hombergii showed significant differences in $\delta^{13} \mathrm{C}$ values among treatments. Within raked plots, mean $\delta^{13} \mathrm{C}$ values for $N$. hombergii were lower than those within control and fished plots $\left(F_{10,36}=3.18, \mathrm{p}=0.005\right)$ with $\mathrm{a}$ mean difference of $1.75 \%$ (Fig. 2). The cockle Cerastoderma edule had significantly lower $\delta^{13} \mathrm{C}$ values in raked and fished plots compared to control plots; however, this was only apparent at Warton Sands $\left(F_{2,24}=4.07, \mathrm{p}=0.03\right)$, with a mean difference of $1.5 \%$ o (Fig. 2).

Significant differences in $\delta^{15} \mathrm{~N}$ values were also observed. $\delta^{15} \mathrm{~N}$ values within the tissues of Nephtys hombergii were significantly lower within raked and fished plots compared to controls (mean differences of $2.15 \%$, $\left.F_{10,36}=6.57, \mathrm{p}<0.001\right) . \delta^{15} \mathrm{~N}$ values for Cerastoderma edule were significantly higher in control plots than fished plots (mean difference of $0.8 \%)\left(F_{2,24}=4.31, \mathrm{p}=0.025\right)$.

Of the 8 species investigated, 2 showed significant differences in isotope ratios following experimental disturbance. Differences were observed in both the $\delta^{13} \mathrm{C}$ and $\delta^{15} \mathrm{~N}$ values of Cerastoderma edule and Nephtys hombergii. Caution is, however, warranted concerning $\delta$ values < $1 \%$ (O'Leary et al. 1992), and so the observed differences in $\delta^{15} \mathrm{~N}$ values for $C$. edule $(0.8 \%$ ) will not be considered further.

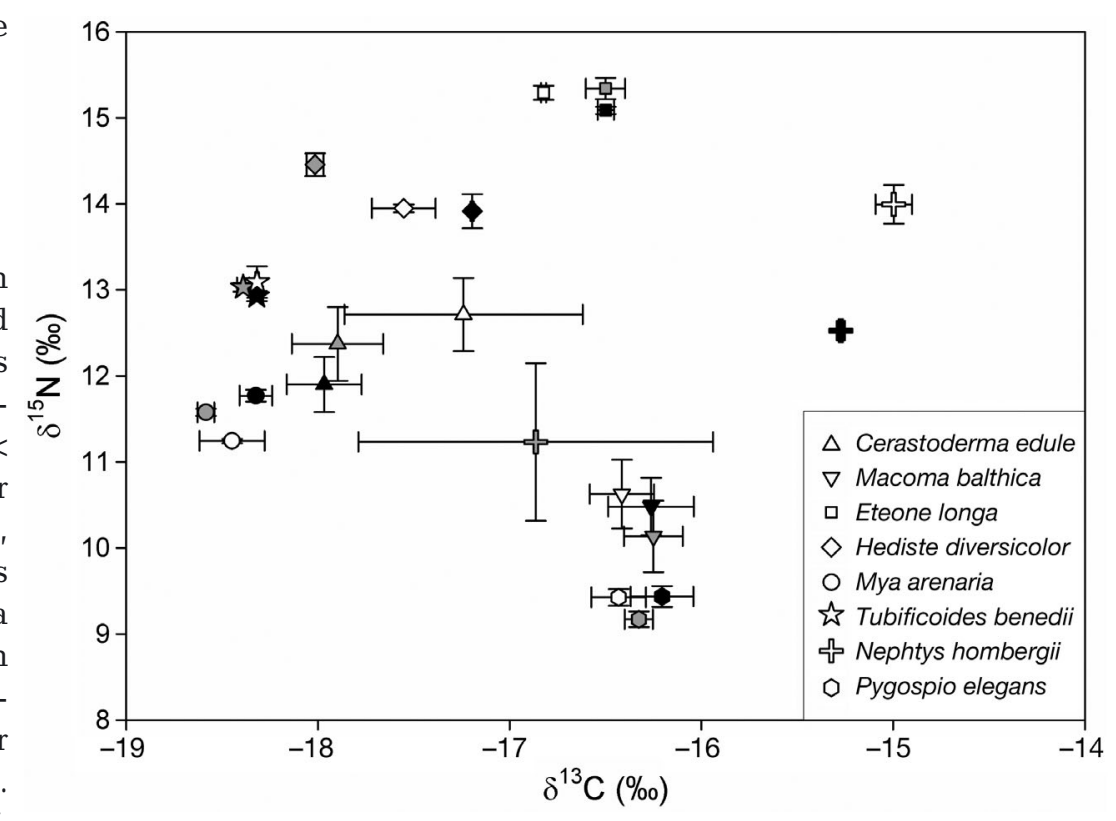

Fig. 2. Mean $\delta^{13} \mathrm{C}$ and $\delta^{15} \mathrm{~N}$ values $( \pm \mathrm{SE})$ for macrofaunal taxa investigated within assemblages at Thurstaston and Warton Sands, England, subjected to the experimental removal of Cerastoderma edule (black symbols), procedural controls (grey symbols) or undisturbed controls (white symbols) 


\section{DISCUSSION}

This study shows that analyses based on functional groups or biological traits can potentially give a misleading representation of the ecological roles carried out by taxa within an assemblage. This has implications for the application of these measures in the assessment of ecosystem functioning. Within our experimental plots, 4 mo after physical disturbance, significant differences in the proportions of carbon and nitrogen stable isotopes between treatments suggested differences in the diet of those taxa that accounted for around $60 \%$ of the living biomass. The data does not allow us to ascertain the specific drivers behind the observed differences. It is possible, for example, that the differences were a result of changes in the feeding behaviour of the macrofauna. Alternatively, the differences may be a product of alterations in the food sources available to taxa, for example, changing the isotopic signature of materials present within the benthos as a result of mixing of aerobic and anaerobic sediments. Regardless of the driver of the observed differences, the results reveal differences in ecosystem functioning between treatments that would not be captured by BTA alone.

The data does, however, indicate differences in the role in the food web of individuals of the same taxa in different treatments over the 4 mo study period and allows inferences to be made regarding the food sources consumed in the various treatments.

Significant reductions in both $\delta^{15} \mathrm{~N}$ and $\delta^{13} \mathrm{C}$ values for the predatory polychaete Nephtys hombergii were evident within disturbed sediments. $\delta^{15} \mathrm{~N}$ values for $N$. hombergii were lower within experimentally raked and fished plots than in controls. This was consistent with increased consumption of food resources from a lower trophic level in disturbed plots. Trophic interactions within natural assemblages are, however, complex. The high degree of connectivity between taxa within food webs means that it is insufficient to assign taxa to rigid and discreet trophic levels (Polis \& Strong 1996); instead, $\delta^{15} \mathrm{~N}$ values often lie along a continuum with only limited clustering of values into discrete trophic levels (e.g. Garcia et al. 2006). The data suggests, therefore, that N. hombergii within experimentally raked and fished plots were consuming a greater proportion of primary consumers (for example, algivorous molluscs and polychaetes) than those within control plots. Nephtys spp. feed on a range of prey, including primary consumers and carnivores (Fauchald \& Jumars 1979), and hence such a difference in feeding preferences is not unfounded. $\delta^{13} \mathrm{C}$ values were consistent with a shift in the feeding behaviour of $N$. hombergii, indicating that $N$. hombergii were feeding closer to the base of the food chain within raked plots. This was not, however, recorded in experimentally fished plots. Future research should test the generality of this finding and explicitly identify the different food sources utilised under different environmental conditions.

Intertidal habitats generally display a degree of functional redundancy, with removal of some fauna having little impact on ecological processes (e.g. Murphy \& Tolhurst 2009). Physical impacts on ecological function have substantial impacts on benthic ecosystems (e.g. Thrush \& Dayton 2002). The suspension and surface deposit feeding cockle Cerastoderma edule showed significant differences in $\delta^{13} \mathrm{C}$ values. This suggests that the food sources being consumed and assimilated differed between experimental treatments. Cockles feed on phytoplankton and microphytobenthos (MPB) (Sauriau \& Kang 2000). A meta-analysis by Doi et al. (2010) showed that MPB have higher mean $\delta^{13} \mathrm{C}$ values than phytoplankton. Significantly lower $\delta^{13} \mathrm{C}$ values in experimentally disturbed plots suggest that $C$. edule within these plots had diets containing a higher proportion of phytoplankton than those in control plots. This is likely to be related to the physical disturbance of surface sediments in disturbed plots resulting in a reduction in the MPB community. Benthic algal communities tend to re-establish over a timescale of days to weeks (Tolhurst et al. 2008), and hence disturbance would necessitate a short-term shift in C. edule feeding towards a diet dominated by phytoplankton.

The current study shows that even relatively smallscale anthropogenic impacts can propagate into alterations in the flow of energy and material in intertidal estuarine assemblages. Anthropogenic impacts on feeding behaviour are also reported within microbial assemblages (e.g. Garstecki \& Wickham 2001), subtidal systems (e.g. Ramsay et al. 1996), lake (Vander Zanden et al. 1999) and meadow habitats (Hawlena et al. 2011).

In the present study, 2 taxa, representing 61 and $71 \%$ of macrofaunal biomass within Thurstaston and Warton Sands, respectively (Cesar \& Frid 2009, C. P. Cesar unpubl. data), showed significant changes in stable isotope ratios following experimental disturbance. As they represent a substantial proportion of the organic carbon within the study systems, they are likely to have an important influence on many ecosystem processes. The observed changes may affect the validity of the inferences that can be made using BTA to assess ecosystem function. That is, following physical disturbance, isotope ratios suggested that 
Cerastoderma edule went from feeding largely from the benthos to a diet consisting of more material from the pelagos. Therefore, following disturbance, there was subsequent increase in benthic-pelagic coupling (albeit over the short term) and this has implications for the transfer and processing of energy and nutrients between the pelagos and the benthos (Loo \& Rosenberg 1996). BTA would reveal no change in trait prevalence and hence no implications for benthic-pelagic coupling or other ecological processes.

Studies on the impacts of disturbance within estuarine and intertidal habitats often reveal no or minimal impacts of disturbance on biodiversity, and from this, it is concluded that ecological processes are also unaffected (e.g. Bolam et al. 2002, Cesar \& Frid 2009, Jones et al. 2011). The current study has shown that taxa living within dynamic and changeable environments are able to respond to changes by altering their behaviour and their expression of functionally important biological traits. It is, therefore, potentially problematic to conclude that no significant change in species composition will also indicate no change in function. This has implications for the use of biological traits in the analysis of ecological function.

Acknowledgements. We thank G. Wolff for valuable advice regarding isotope analyses, J. Bremner for comments on an early draft and 3 anonymous referees for their valuable comments. This work was funded by the University of Liverpool as part of C.P.C.'s PhD research.

\section{LITERATURE CITED}

Anger K, Anger V, Hagmeier E (1986) Laboratory studies on larval growth of Polydora ligni, Polydora ciliata, and Pygospio elegans (Polychaeta, Spionidae). Helgol Mar Res 40:377-395

Baird DJ, Rubach MN, van den Brink PJ (2008) Trait-based ecological risk assessment (TERA): the new frontier? Integr Environ Assess Manag 4:2-3

$>$ Bolam SG, Fernandes TF, Huxham M (2002) Diversity, biomass and ecosystem processes in the marine benthos. Ecol Monogr 72:599-615

- Bremner J, Rogers SI, Frid CLJ (2006) Methods for describing ecological functioning of marine benthic assemblages using biological traits analysis (BTA). Ecol Indic 6: 609-622

- Cesar CP, Frid CLJ (2009) Effects of small-scale cockle (Cerastoderma edule L.) fishing on ecosystem function. Mar Ecol 30:123-137

> Chevene F, Dolédec S, Chessel D (1994) A fuzzy coding approach for the analysis of long-term ecological data. Freshw Biol 31:295-309

> de Goeij P, Luttikhuizen P (1998) Deep-burying reduces growth in intertidal bivalves: field and mesocosm experiments with Macoma balthica. J Exp Mar Biol Ecol 228: 327-337

> Doi H, Kikuchi E, Shikano S, Takagi S (2010) Differences in nitrogen and carbon stable isotopes between planktonic and benthic microalgae. Limnology 11:185-192

Esselink P, Zwarts L (1989) Seasonal trend in burrow depth and tidal variation in feeding activity of Nereis diversicolor. Mar Ecol Prog Ser 56:243-254

Fauchald K, Jumars PA (1979) Diet of worms: a study of polychaete feeding guilds. Oceanogr Mar Biol Annu Rev 17:193-284

Frid CLJ, Paramor OAL, Brockington S, Bremner J (2008) Incorporating ecological functioning into the designation and management of marine protected areas. Hydrobiologia 606:69-79

Froneman PW (2001) Seasonal changes in zooplankton biomass and grazing in a temperate estuary, South Africa. Estuar Coast Shelf Sci 52:543-553

Garcia AM, Hoeinghaus DJ, Vieira JP, Winemiller KO, Motta Marques DML, Bemvenuti MA (2006) Preliminary examination of food web structure of Nicola Lake (Taim Hydrological System, south Brazil) using dual $\mathrm{C}$ and $\mathrm{N}$ stable isotope analyses. Neotrop Ichthyol $4: 279-284$

Garstecki T, Wickham SA (2001) Effects of resuspension and mixing on population dynamics and trophic interactions in a model benthic microbial food web. Aquat Microb Ecol 25:281-292

Giere O, Felbeck H, Dawson R, Liebezeit G (1984) The gutless oligochaete Phallodrilus leukodermatus Giere, a tubificid of structural, ecological and physiological relevance. Hydrobiologia 115:83-89

Gudmundsson H (1985) Life history patterns of polychaete species of the family Spionidae. J Mar Biol Assoc UK 65: 93-111

> Hawlena D, Hughes KM, Schmitz OJ (2011) Trophic trait plasticity in response to changes in resource availability and predation risk. Funct Ecol 25:1223-1231

Jones HFE, Pilditch CA, Bruesewitz DA, Lohrer AM (2011) Sedimentary environment influences on the effect of an infaunal suspension feeding bivalve on ecosystem function. PLoS ONE 6: e27065

> Jonsson M, Malmqvist B (2000) Ecosystem process rate increases with animal species richness: evidence from leaf-eating, aquatic insects. Oikos 89:519-523

> Kamermans P (1993) Food limitation in cockles (Cerastoderma edule (L.)): influences of location on tidal flat and of nearby presence of mussel beds. Neth J Sea Res 31: $71-81$

Kamermans P (1994) Similarity in food source and timing of feeding in deposit- and suspension-feeding bivalves. Mar Ecol Prog Ser 104:63-75

> Loo LO, Rosenberg R (1996) Production and energy budget in marine suspension feeding populations: Mytilus edulis, Cerastoderma edule, Mya arenaria and Amphiura filiformis. J Sea Res 35:199-207

Lorrain A, Paulet YM, Chauvaud L, Savoye N, Donval A, Saout C (2002) Differential $\delta^{13} C$ and $\delta^{15} N$ signatures among scallop tissues: implications for ecology and physiology. J Exp Mar Biol Ecol 275:47-61

Mermillod-Blondin F, François-Carcaillet F, Rosenberg R (2005) Biodiversity of benthic invertebrates and organic matter processing in shallow marine sediments: an experimental study. J Exp Mar Biol Ecol 315:187-209

Michaelis H, Vennemann L (2005) The 'piece-by-piece predation' of Eteone longa on Scolelepis squamata (Polychaetes) - traces on the sediment documenting chase, defence and mutilation. Mar Biol 147:719-724 
Murphy RJ, Tolhurst TJ (2009) Effects of experimental manipulation of algae and fauna on the properties of intertidal soft sediments. J Exp Mar Biol Ecol 379:77-84

Nichols FH (1985) Increased benthic grazing: an alternative explanation for low phytoplankton biomass in northern San Francisco Bay during the 1976-1977 drought. Estuar Coast Shelf Sci 21:379-388

O'Leary MH, Madhavan S, Paneth P (1992) Physical and chemical basis of carbon isotope fractionation in plants. Plant Cell Environ 15:1099-1104

Polis GA, Strong DR (1996) Food web complexity and community dynamics. Am Nat 147:813-846

$>$ Powell EN, Bright TJ, Woods A, Gittings S (1983) Meiofauna and the thiobios: another look at the East Flower Garden brine sweep. Mar Biol 73:269-283

Ramsay K, Kaiser MJ, Hughes RN (1996) Changes in hermit crab feeding patterns in response to trawling disturbance. Mar Ecol Prog Ser 144:63-72

Rönn C, Bonsdorf E, Nelson W (1988) Predation as a mechanism of interference within infauna in shallow brackish water soft bottoms; experiments with an infauna predator, Nereis diversicolor O.F.Müller. J Exp Mar Biol Ecol 116:143-157

Sarakinos HC, Johnson ML, Zanden MJV (2002) A synthesis of tissue-preservation effects on carbon and nitrogen

Editorial responsibility: Martin Solan,

Southampton, UK stable isotope signatures. Can J Zool 80:381-387

Sauriau PG, Kang CK (2000) Stable isotope evidence of benthic microalgae-based growth and secondary production in the suspension feeder Cerastoderma edule (Mollusca, Bivalvia) in the Marennes-Oléron Bay. Hydrobiologia 440:317-329

> Thrush SF, Dayton PK (2002) Disturbance to marine benthic habitats by trawling and dredging: implications for marine biodiversity. Annu Rev Ecol Syst 33:449-473

$>$ Tolhurst TJ, Consalvey M, Paterson DM (2008) Changes in cohesive sediment properties associated with the growth of a diatom biofilm. Hydrobiologia 596:225-239

Vander Zanden MJ, Casselman JM, Rasmussen JB (1999) Stable isotope evidence for the food web consequences of species invasions in lakes. Nature 401:464-467

Vedel A (1998) Phytoplankton depletion in the benthic boundary layer caused by suspension-feeding Nereis diversicolor (Polychaeta): grazing impact and effect of temperature. Mar Ecol Prog Ser 163:125-132

Wilson WH (1985) Food limitation of asexual reproduction in a spionid polychaete. Int J Inver Rep Dev 8:61-65

Zak DR, Holmes WE, White DC, Peacock AD, Tilman D (2003) Plant diversity, soil microbial communities, and ecosystem function: are there any links? Ecology 84: 2042-2050

Submitted: December 23, 2011; Accepted: July 10, 2012

Proofs received from author(s): October 8, 2012 